\title{
"Bonita" \\ natureza e romantismo, forma e canção em Tom Jobim
}

\author{
Gabriel S. S. Lima Rezende ${ }^{1}$ \\ Rafael dos Santos ${ }^{2}$
}

\section{Resumo}

Neste artigo se discute o papel que a natureza cumpre em dois âmbitos distintos da trajetória de Tom Jobim. Partindo do mais explícito, o ecológico, aborda-se a questão que gira em torno da erosão da natureza pela ação do homem e da busca por uma experiência integradora. Essa discussão abre as portas para o problema central do artigo, situado no âmbito menos evidente da produção estética: delimitar e analisar o papel que a natureza cumpre na elaboração formal da canção "Bonita". A análise é mediada por considerações sobre certas transformações ocorridas na esfera da produção de música popular no Brasil na década de 1950, e alinhavada pela discussão a respeito da incorporação de aspectos do romantismo no pensamento e na obra de Jobim. Por fim, apresenta-se uma problematização que coloca em relação os dois âmbitos de sua trajetória que foram comentados: ecologia e estética ${ }^{3}$.

\section{Palavras-chave}

Bonita, Tom Jobim, Natureza, forma e canção, romantismo.

Recebido em 6 de março de 2014

Aprovado em 7 de julho de 2014

LIMA REZENDE, Gabriel S. S.; SANTOS, Rafael dos. "Bonita": natureza e romantismo, forma e canção em Tom Jobim. Revista do Instituto de Estudos Brasileiros, Brasil, n. 59, p. 97-128, dez. 2014. DOI: http://dx.doi.org/10.11606/issn.2316-901X.v0i59p97-128

1 Universidade Federal da Integração Latinoamericana (Unila, Foz do Iguaçu, PR, Brasil).

2 Universidade Estadual de Campinas (Unicamp, Campinas, SP, Brasil).

3 Este trabalho é resultado da reelaboração e da ampliação da comunicação "Bonita': natureza, canção e forma em Tom Jobim”, apresentada no XXIII Congresso da ANPPOM, Natal, 2013. 


\title{
"Bonita" \\ Nature and Romanticism, Form and Song in Tom Jobim
}

\author{
Gabriel S. S. Lima Rezende \\ Rafael dos Santos
}

\section{Abstract}

This article discusses the role of nature in two spheres of Tom Jobim's trajectory. Starting from the most evident, ecology, it addresses the question of erosion by human experience and the search for an integrating experience. This discussion opens the door to the central problem of the article, situated in the less clear sphere of aesthetic production: to define and analyse the role that nature plays in the formal establishment of "Bonita". The investigation is mediated by considerations about certain transformations in the production of popular music in Brazil in the 1950s, and tacked by the discussion about the incorporation of aspects of romanticism in the thought and the work of Jobim. Finally, it presents a problem that links the two spheres of his career previously commented: ecology and aesthetics.

\section{Keywords}

Bonita, Tom Jobim, Nature, form and song, romanticism. 


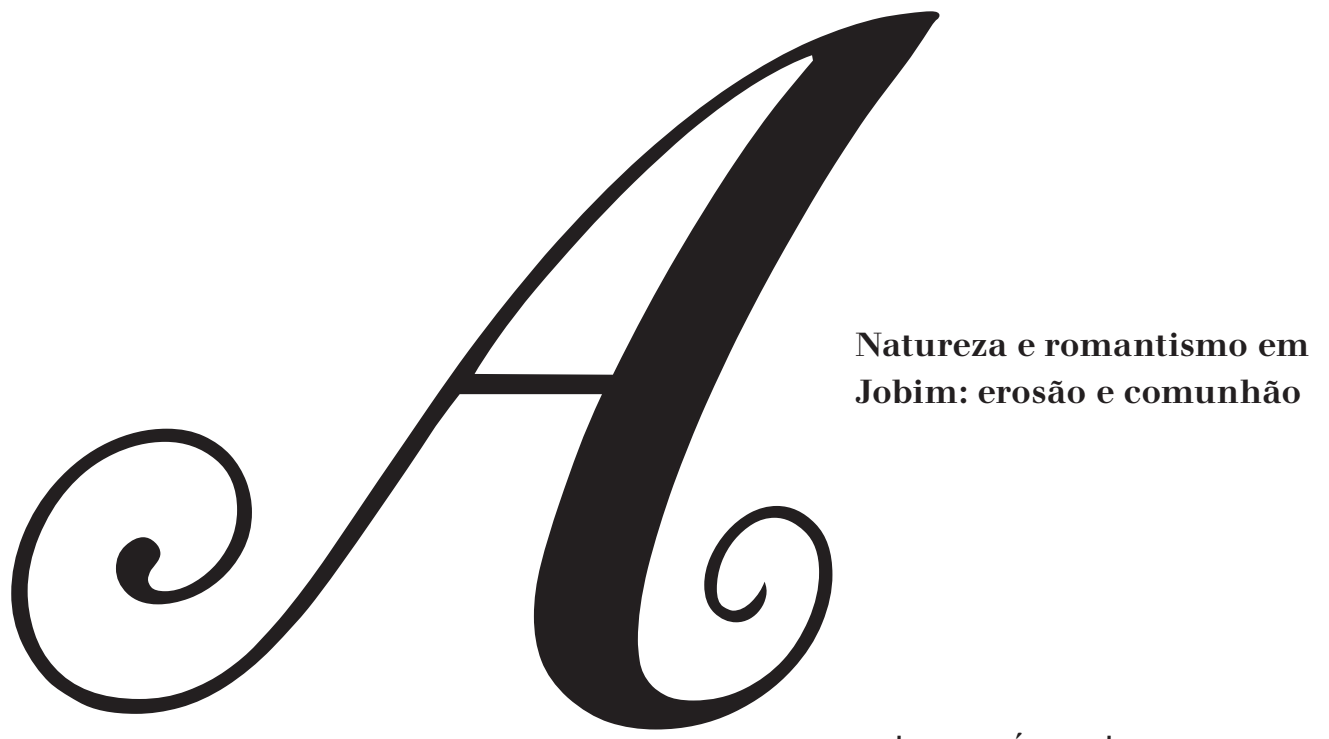

natureza é um tema recorrente na trajetória de Tom Jobim. Estamos acostumados a encontrá-la vinculada ao problema da sua "erosão" - para utilizar um termo que aparece repetidamente nas entrevistas dadas pelo compositor - pela ação do homem. Em uma dessas entrevistas, concedida a Carlos Lacerda e publicada numa edição de 1970 da Revista Manchete, Jobim comenta:

Pode ser que a nossa civilização seja muito avançada. Mas, faz muita fumaça. É uma fumaceira subindo... No ABC paulista, no Rio, em Nova Iorque, Los Angeles... Então, é a lenha, botar o mar pra baixo, matar os pássaros e depois, quando não houver mais árvores, é botar fogo no capim - se pegar fogo. E a erosão é aquela coisa. O mundo cai mais eles varrem. Cai tudo dentro do sumidouro. $^{4}$

Curiosamente, esse comentário de Jobim - que vincula de maneira clara, e com ironia velada, o suposto estágio avançado da civilização ocidental com a projeção de uma catástrofe ambiental - aparece para contestar a seguinte provocação de seu interlocutor: "Sua atitude [a de Jobim] diante da mecanização do mundo e da ruína da natureza é romântica". ${ }^{5}$ Embora a designação "romântico" não seja capaz de esclarecer

4 LACERDA, Carlos. A vida numerosa e tensa de Antônio Carlos Jobim. Revista Manchete, Rio de Janeiro, 197o, p. 45. Disponível em: http://www.jobim.org/jobim/ bitstream/handle/2010/10358/pim529.pdf?sequence=10. Acesso em: 27 fev. 2014 .

5 Ibidem, p. 45 . 
plenamente esse aspecto do pensamento e das ações de Jobim ${ }^{6}$, parece inegável que eles incorporam algo daquela "visão de mundo" que se disseminou pela Europa ao longo do século XIX, sobretudo no que se refere aos problemas advindos do avanço das sociedades urbano-industriais a partir da segunda metade daquele século. Nesse sentido, numa entrevista do mesmo ano, publicada no Jornal do Brasil, o compositor lamenta: "Não existem mais praias na Guanabara. Existem Volkswagens. Existe poluição: estragar o mar, tão indestrutível. É o progresso".7

É justamente nesse período que surge uma série de canções de Jobim que Nestrovski reúne sob a designação de "músicas ecológicas": Chovendo na Roseira, O Boto, Correnteza, Passarim e Águas de Março ${ }^{8}$. Esta última se singulariza pelo tratamento dado à temática: a construção de oposições para serem diluídas pelas "águas" que encerram o verão. Nessa dinâmica, as imagens da "erosão" - entendida como força desagregadora da relação entre homem e natureza - são contrapostas a imagens que brotam de uma experiência integradora. Algo da busca por essa experiência já se havia manifestado, por exemplo, na citada entrevista ao Jornal do Brasil, particularmente no momento em que o compositor comenta que leu "um livro de um cara lá no sítio":

Ele fala, rapaz, como ser feliz em dez alqueires de terra. Ensinar a plantar o feijão das águas, o feijão da seca, o feijão de vara, as épocas, a chuva, né? E diz que a casa deve ser feita em lugar alto, ventilado, soalheiro... Soalheiro! Não é genial? Ensina a fazer, a plantar cana, a fazer garapa, o vinagre, a cachaça, o açúcar mascavo e branco, né? Ensina a castrar os porcos, a estrumar a terra, a revezar as... Como se diz? Você não pode plantar sempre no mesmo lugar, porque senão a terra fica cansada né? Oh meu Deus, como se diz? A erosão né? O problema da erosão... fazer marmelada, goiabada, pessegada... ${ }^{9}$

6 Entre as ações do compositor que podem ser interpretadas como orientadas por uma preocupação ecológica, e não necessariamente romântica, destacam-se, por exemplo, a apresentação no Rio ECO-92 e os shows beneficentes para a "Rain Forest Foundation".

7 COELHO, Frederico O.; CAETANO, Daniel (orgs.). Tom Jobim. Rio de Janeiro: Beco do Azougue, 2011, p. 136.

8 NESTROVSKI, Arthur. $O$ samba mais bonito do mundo. In: MAMMI, Lorenzo; NESTROVSKI, Arthur; TATIT, Luiz. Três canções de Tom Jobim. São Paulo: Cosac Naify, 2004, p. 35. Conferir também o comentário de Freitas à análise apresentada por Nestrovski em FREITAS, Sérgio. P. R. de. Que acorde ponho aqui? Harmonia, práticas teóricas e o estudo de planos tonais em música popular. 2010. xlii+817 p. Tese (Doutorado em Música) - Instituto de Artes, Universidade Estadual de Campinas, 2010, p. 142-43.

9 COELHO, Frederico O.; CAETANO, Daniel (orgs.). Tom Jobim, p. 134. 
A felicidade buscada num movimento de regresso à comunhão perdida com a natureza aparece, portanto, como contrapartida ideal à "erosão" causada pela ação do homem, pelo progresso e pela civilização. Uma visão da natureza colorida por matizes românticos ganha, assim, uma configuração positiva. Subjacente a isso podemos encontrar uma dinâmica que percorre distintos âmbitos e momentos da trajetória de Jobim: a formação de polos antagônicos e complementares. Entretanto, a progressiva superação, mais do que a diluição, parecia ser o modo preferido pelo qual o compositor tratava os conflitos que esses polos engendram.

\section{Transição: o criador e a criação}

O interesse romântico pela natureza toca, ainda que indiretamente, em um aspecto que consideramos importante para a compreensão da obra de Jobim, de modo que, a partir de agora, nos esforçaremos para trazê-lo à tona e evidenciar seu sentido no contexto da produção de canção brasileira da segunda metade do século XX. Para alcançar esse objetivo continuaremos seguindo as pistas deixadas por ideais e expressões de caráter romântico que se encontram dispersos nas entrevistas realizadas com o compositor.

Em outra dessas entrevistas, Clarice Lispector pergunta sobre os indícios de que uma nova canção estaria por nascer, ao que Jobim responde:

As dores do parto são terríveis. Bater com a cabeça na parede, angústia, o desnecessário do necessário, são os sintomas de uma nova música nascendo. Eu gosto mais de uma música quanto menos eu mexo nela. Qualquer resquício de savoir-faire me apavora." 10

Sabe-se que o doloroso processo da criação enquanto irrupção de angústias, conflitos, emoções incontroláveis etc. na forma de produto artístico é uma das peças mais importantes no processo de construção da representação romântica do artista. Mas concentremos nossas atenções na sua contrapartida, a criação. Ela será tanto melhor quanto menos "know how", quanto menos "saber fazer", em outras palavras, quanto menos artifício estiver envolvido em sua configuração. Sua espontaneidade a conectaria de forma mais direta ao conteúdo emotivo que

10 COELHO, Frederico O.; CAETANO, Daniel (orgs.). Tom Jobim, p. 146. 
impulsionou o processo criativo. Dando continuidade à discussão sobre o tema da criação, Lispector formula a seguinte questão: "Muitas vezes, nas criações em qualquer domínio, pode-se notar tese, antítese e síntese. Você sente isso nas suas criações? Pense". Como bom conhecedor que é dos artifícios de seu ofício, Jobim responde: "Sinto demais isso. Sou um matemático amoroso, carente de amor e de matemática. Sem forma não há nada". ${ }^{11}$ A interpretação dessa resposta também requer certo cuidado para que a atenção não se deixe seduzir pelo que é mais reluzente. Tanto o coexistir dos opostos (matemática e amor/ razão e emoção) quanto o cantar aquilo que não se possui também constituem traços importantes da configuração romântica do artista. Mas há uma questão mais sutil que se esconde nas entrelinhas da pergunta de Lispector e da resposta de Jobim, e que tem importância decisiva para este trabalho. Em momento algum da formulação da literata colocou-se explicitamente o problema da forma, e em momento algum da resposta do compositor apareceu o mecanismo de sua constituição: aquilo sobre o que se falava era demasiado óbvio para ambos para necessitar maiores explicações. A ordenação lógica do pensamento artístico em torno da dinâmica entre os três momentos da dialética é um dos principais artifícios de construção formal. Ao mesmo tempo, enquanto síntese dos conflitos instaurados ao longo da criação, a aparência estética deve ser capaz de encobrir o mecanismo de constituição da obra, o artifício, e, desse modo, apresentar o produto artístico como algo espontâneo ${ }^{12}$, "que cai no ouvido como uma fruta cai do galho". ${ }^{13}$

\section{O problema da forma na canção}

O fato de que o problema da forma, do modo como ele foi levantado, tenha surgido com tanta naturalidade para Jobim pode ser interpretado como um indício de que a esfera da produção de música popular no Brasil,

11 COELHO, Frederico O.; CAETANO, Daniel (orgs.). Tom Jobim, p. 147.

12 Esta era uma busca que não particularizava a produção artística orientada por valores e anseios próprios a concepções românticas da criação artística, nem as construções teóricas a elas vinculadas, senão quando inserida num conjunto mais amplo de noções - como as de genialidade, divindade e irracionalidade do impulso criativo, supremacia da expressão individual perante as convenções etc. -, dentro do qual cumpre funções específicas. A repercussão de ideais e valores relacionados com o pensamento romântico oitocentista no campo da música popular massiva do século XX dá-se principalmente pela via do senso comum. Essas questões são brevemente rediscutidas ao final do trabalho (conferir nota de rodapé n. 48).

13 NESTROVSKI, Arthur. O samba mais bonito do mundo, p. 36 . 
mais especificamente de canções, tinha passado por importantes transformações. Estas podem ser encontradas com especial nitidez a partir da década de 1950. Espelhando os próprios anseios de uma parcela significativa de compositores, intérpretes, críticos, produtores etc. e, de um modo mais amplo, o próprio "espírito do tempo", a bibliografia identificou naquele período um momento de "modernização" da música popular4, momento que, por sua vez, responde a um contexto no qual a expansão da cultura de massas e, mais especificamente, o desenvolvimento do setor radiofônico e a ampla circulação de produtos musicais internacionais, estimularam diversas formas de posicionamento estético-ideológico por parte de compositores, intérpretes, jornalistas, críticos etc. A relativa ordenação do campo musical que resultou dessa situação envolveu um esforço de reflexão sobre o passado e o futuro da música popular no Brasil, esforço que se cristalizou, por exemplo, na conformação de uma "época de ouro" dessa música, algo que contribuiu para organizar a atuação tanto de agentes que se identificavam com valores e ideais "tradicionalistas" quanto daqueles que assumiam posicionamentos considerados "modernos". Importa aqui destacar que tal esforço reflexivo não se desdobrava apenas em discursos verbais, manifestando-se também no âmbito intrínseco da criação artística, mas especificamente, no da articulação interna entre elementos poético-musicais. Nesse sentido, trabalhos como o de Lorenzo Mammí ${ }^{15}$ e Walter Garcia ${ }^{16}$ mostram como, no plano da interpretação, esse "ímpeto modernizador" se traduziu num movimento de auto reflexão da canção que incide na própria ordenação dos elementos estético-musicais entre si e em suas vinculações com a poesia ${ }^{17}$. Evidentemente, isso não constituiu uma especificidade do desenvolvimento da música popular no Brasil, e, mesmo aqui, não se tornou uma regra geral da produção de canções. Mesmo assim, não há como contestar que aquele movimento teve consequências importantes para a história dessa música no país, como demonstram tanto o crescente interesse que ele tem despertado em pesquisadores de distintas áreas do conhecimento nas últimas décadas quanto os próprios acontecimentos

14. Conferir, por exemplo, SEVERIANO, Jairo. Uma história da música popular brasileira. São Paulo: Editora 34, 2008.

15 MAMMI, Lorenzo. João Gilberto e o projeto utópico da bossa nova. Novos Estudos Cebrap, São Paulo, n. 34, p. 63-70, 1992.

I6 GARCIA, Walter. Bim Bom: a contradição sem conflitos de João Gilberto. São Paulo: Paz e Terra, 1999.

17 O próprio Jobim se referia a esse momento de reorientação das práticas musicais como algo consciente e intencionalmente buscado. Conferir a entrevista dada a Zuza Homem de Mello em 1968, e publicada em COELHO, Frederico O.; CAETANO, Daniel (orgs.). Tom Jobim, p. 102. 
da segunda metade da década de 1960. Nesse sentido, as reflexões apresentadas neste estudo se alinham às perspectivas de autores que buscam compreender como a questão da modernização se traduz no interior das criações musicais. Mais especificamente, queremos entender como o problema da modernização dos gêneros populares que se consolida como momento importante da experiência da música popular no Brasil a partir da década de 1950 - e mais especificamente, o modo como esse problema se desdobra em práticas auto reflexivas que incidem sobre a articulação interna dos elementos poéticos e estético-musicais - atinge a própria configuração formal das composições. A relação entre auto reflexão e forma se apresenta de maneira clara quando a análise de certas composições revela que estruturas formais da canção, que muitas vezes já estavam dadas de antemão e que eram incorporadas e reproduzidas de modo mais ou menos naturalizado, passam a ser objeto de especulação ${ }^{18}$. Nesse sentido, a análise de determinadas canções de Tom Jobim parece ser um caminho privilegiado para a compreensão de certos aspectos do problema da modernização da música popular ${ }^{19}$, dado que tais aspectos se manifestam com maior nitidez no plano das relações internas entre os elementos poético-musicais ${ }^{20}$. A resposta dada

18 Isso deve ser entendido como uma perspectiva heurística capaz orientar o pesquisador no estudo de certos aspectos que envolvem a produção de música popular no Brasil a partir dos anos 5o, em especial a problemática da passagem de uma "época de ouro" para um momento de modernização dos gêneros populares. De modo algum tal perspectiva pretende criar uma divisão estanque na qual a produção de música popular anterior aos anos 50 não apresentaria manifestações de reflexividade com o material musical e iniciativas de especulação formal.

19 Conferir, por exemplo, a análise de "Chega de Saudade" em LIMA REZENDE, Gabriel. S. S. O problema da tradição na trajetória de Jacob do Bandolim: comentários à história oficial do choro. 2014. 443f. Tese (Doutorado em Música) - Instituto de Artes, Universidade Estadual de Campinas, 2014.

20 O potencial que essas obras têm de iluminar problemas de ordem histórico-social não se deve somente ao "talento" de Jobim enquanto propriedade interna do criador, mas também a diversas condições objetivas como o próprio processo de educação e formação musical do compositor, as situações que o levaram a profissionalizarse, o ambiente musical no qual ele se inseriu e as referências que ele procurou etc. - fatores já amplamente comentados pela bibliografia (conferir, por exemplo, POLETTO, Fábio G. Tom Jobim e a modernidade musical brasileira: 1953-1958. 2004. 148 f. Dissertação (Mestrado em História) - Departamento de História, Universidade Federal do Paraná, 2004 ) bem como as transformações na base material de produção musical, sobretudo o conjunto de inovações reunidas sob o slogan $\mathrm{Hi}$-Fi, que possibilitavam uma percepção mais sutil dos eventos sonoros captados, algo que certamente incidiu na esfera dos valores estéticos (conferir ZAN, José Roberto; NOBRE, Marcos. A canção e a vaia. Folha de São Paulo, São Paulo, o5 dez. 2010. Ilustríssima. Disponível em http://www1.folha.uol.com.br/fsp/ ilustrissima/ilo512201007.htm. Acesso em: 25 de março de 2013). 
pelo compositor à pergunta de Lispector oferece pistas importantes para a compreensão de como se realizava essa reflexão especulativa com os elementos formais da canção e dos valores que a orientavam. Cumprir essa tarefa é o próximo objetivo deste trabalho. Para alcançá-lo, concentraremos nossas atenções na análise de "Bonita" (Jobim/Lees/Gibert).

\title{
Natureza e romantismo em Jobim: "Bonita"
}

\author{
"Simples, o poder se cerra na \\ semente; um modelo incipiente \\ Jaz, fechado em si, dobrado sob o \\ invólucro \\ Folha e raiz e broto, apenas semi- \\ configurados e sem cor; \\ Seco, conserva assim o grão, \\ resguardada, uma vida tranquila \\ Subitamente irrompe para cima, se \\ confia à umidade benfazeja \\ E ergue-se pronto da noite \\ circundante. \\ [...]. \\ E assim ela alcança do início a \\ mais alta perfeição determinada, \\ Que em muitas espécies te levam ao \\ assombro"
}

(Die Metamorphose der Pflanzen [A metamorfose das plantas], Goethe)

Entre 1964 e 1969 "Bonita" recebeu três gravações diferentes em momentos importantes da trajetória de Jobim. Lançada no LP The Wonderful World of Antonio Carlos Jobim (1964), voltaria a ser registrada e publicada, dois anos mais tarde, em A Certain Mr. Jobim (1967). No final da década, ela também foi incluída no repertório planejado para compor o segundo trabalho da parceria com Frank Sinatra, que visava explorar o sucesso comercial do Francis Albert Sinatra \& Antônio Carlos Jobim (1967); entretanto, o Sinatra-Jobim (1970) foi rapidamente tirado de circulação, e a gravação só se popularizou no final da década de 1970 
com o lançamento, no Brasil, do LP duplo resultante da compilação das músicas registradas pela parceria, o Sinatra-Jobim Sessions (1979).

O momento decisivo para a conformação e lapidação da ideia que sustenta a composição materializou-se na versão lançada em 1967. Apontam nesse sentido, por exemplo, tanto a insatisfação que teria levado Jobim a regravar a canção recém-estreada em The Wonderful World..., quanto o fato de "Bonita" figurar como a música de abertura do $A$ Certain Mr. Jobim. E, mesmo que na superfície estivesse em pauta a melhora da performance vocal do compositor ou a reformulação do arranjo que vestiu o primeiro registro da composição ${ }^{21}$, há algumas mudanças pontuais em sua estrutura que dão notícia daquele processo de conformação e lapidação.

A mais visível dessas mudanças é justamente a inclusão de uma seção que potencializa as relações entre as partes da obra, dando-lhes uma coesão capaz de alçar a ideia da composição sobre suas contingências históricas ${ }^{22}$. Apesar disso, ela se apresenta no fluxo dessas

21 DUARTE, Luiz de Carvalho. Tom Jobim e Claus Ogerman: uma ontologia do arranjo musical. Revista Brasileira de Música, Rio de Janeiro, v. 25, n. 1, p. 131156, 2012, p. 134. Disponível em: http://musica.ufrj.br/index.php?option=com content\&view $=$ article $\& \mathrm{id}=1460: \mathrm{rbm}-\mathrm{discute}-\mathrm{a}-\mathrm{musica}-\mathrm{popular} \& \mathrm{catid}=66:$ pos graduacao\&Itemid=86. Acesso em: 2 fev. 2014 .

22 Tanto a permanência de certos elementos quanto a supressão de outros aponta para uma depuração dessa ideia. Ainda que o recorte temporal privilegiado neste trabalho remeta à segunda metade da década de 1960 , é evidente que os problemas fundamentais com os quais ele trabalha não nascem nem se esgotam nesse período. Nesse sentido, as partituras publicadas no songbook produzido e editado por Chediak e no cancioneiro editado por Paulo Jobim também foram tomados como textos de referência para as análises aqui desenvolvidas. CHEDIAK, Almir. Songbook Tom Jobim. Rio de Janeiro: Lumiar, 199o, v. 3; JOBIM, Paulo (ed.) Cancioneiro Jobim - Obras Escolhidas. Rio de Janeiro: Jobim Music/ Casa da Palavra, 200o. As palavras que abrem o prefácio a esta última obra remetem justamente à necessidade, sublinhada diversas vezes em diferentes entrevistas do compositor (cf. COELHO, Frederico O.; CAETANO, Daniel (orgs.). Tom Jobim, p. 57, 165 e 176), de "emancipar" as ideias das "contingências históricas": "Durante anos a fio, quase como uma obsessão, o músico Antônio Carlos Brasileiro de Almeida Jobim (1927 1994) concentrou-se em escrever e reescrever partituras de sua obra. O compositor acreditava que assim forneceria muito mais informação sobre suas músicas do que uma simples melodia com cifra. Temia a ação do tempo.” JOBIM, Paulo (ed.) Cancioneiro Jobim - Obras Escolhidas, grifo nosso). Essa busca pela permanência em um universo tão sujeito a interferências transformadoras das mais distintas ordens, como é o da música popular, também se verifica de maneira imediata, nas cifragens apresentadas nos referidos livros. Em relação a "Bonita", a pesar de algumas diferenças pontuais, as obras de Chediak e Jobim apresentam coincidências nos acordes indicados que, além de nada evidentes, não correspondem plenamente a nenhuma das três gravações aqui mencionadas. É muito provável que elas tenham se baseado em indicações do próprio Tom Jobim, nas quais se cristalizaram 
contingências: ausente na primeira gravação ${ }^{23}$, a seção introdutória da versão lançada em 1967 é substituída por outro ambiente de preparação no registro realizado alguns anos mais tarde. A diferença entre ambas, entretanto, é clara: a última, que não alcançou maior transcendência histórica, está baseada em uma variação da figura melódica dos quatro primeiros compassos da seção B sobre a textura harmônico-contrapontística dos compassos iniciais da seção A, enquanto a introdução incluída na gravação lançada em 1967 (Figura 1), que serve de referência para diversas gravações posteriores da canção e que foi incluída nas transcrições publicadas em songbooks ${ }^{24}$, apresenta material harmônico-melódico próprio, que contém virtualmente os principais desdobramentos da composição enquanto unidade formal.

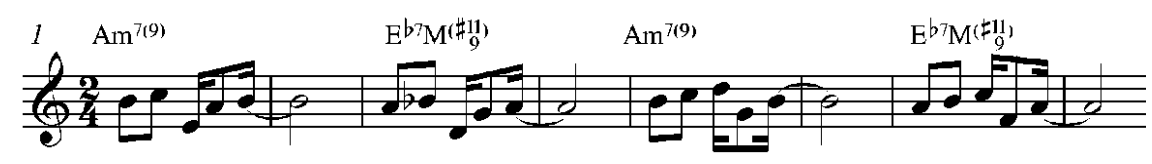

Figura 1: Seção introdutória de "Bonita".

Diferentemente do que ocorre no corpo da canção "Hino ao Sol" (Jobim/Blanco), no qual a relação de trítono entre Eb7M e A7M, pré-anunciada por cadências de tipo dois-cinco, é entreposta pela breve tonicização do $\mathrm{C}^{2} \mathrm{M}^{25}$, nesta seção introdutória de "Bonita" a relação entre Am7 e Eb7M(\#11) é apresentada imediatamente. Talvez não seja mero acaso que tal relação de trítono se assemelhe, no nível da aparência, à alternância entre sol menor e ré bemol maior no quarto movimento da "Sinfonia Fantástica" (1830), obra que rendeu a Berlioz a simpatia

momentos de depuração e explicitação de certos elementos estruturais de suas composições.

23 Consultamos também o manuscrito digitalizado do arranjo de "Bonita" composto por Nelson Riddle e registrado na referida gravação. Cf. RIDDLE, Nelson. Bonita. Arranjo em partitura manuscrita. S/l, s/d, 21 p. Disponível em: http:// www.jobim.org/jobim/bitstream/handle/2010/7697/bonita\%2onelson\%2oriddle. pdf? sequence=22. Acesso em: 3 fev. 2014.

24 CHEDIAK, Almir. Songbook Tom Jobim, p. zo-z1 e JOBIM, Paulo (ed.) Cancioneiro Jobim - Obras Escolhidas, p. 92-94. A importância do Cancioneiro Jobim como registro das ideias do compositor não deve ser subestimada. Segundo o próprio Jobim: "Só eu e meu filho Paulinho sabemos tudo das minhas músicas, de como devem ser tocadas. Tenho de botar tudo isso no papel. Por enquanto, é até bom a gente andar em aviões separados" COELHO, Frederico O.; CAETANO, Daniel (orgs.). Tom Jobim, p. 176.

25 Conferir FREITAS, Sérgio. P. R. de. Ciclos de terças em certas canções da música popular no Brasil. Per Musi, Belo Horizonte, n. 29, p. 125-146, 2014, p. 128-130. DOI: http://dx.doi.org/10.159o/s1517-75992014000100014 
da juventude romântica ${ }^{26}$. Acaso ou não, o importante aqui é notar que não se trata apenas de um recurso colorístico ou de uma sequência aparentemente intrincada evocada meramente para surpreender a expectativa do ouvinte. Os desdobramentos da composição revelam, aos poucos, o caráter seminal dessa seção introdutória, de modo que é a própria forma da canção que brotará do procedimento aparentemente arbitrário contido nos oito compassos iniciais.

Entretanto, a aparente naturalidade com a qual o corpo da canção se desenvolve é a própria ilusão que oculta os artifícios empregados em sua constituição. O início da seção A reforça a aparência de que a composição estaria na tonalidade de lá menor. Ao longo dos 16 compassos iniciais nos quais esta se afirma, o ritmo harmônico dilatado e a melodia girando em torno de uma nota são compensados por uma linha cromática em segundo plano. De modo que a condução linear do primeiro segmento de oito compassos poderia ser representada conforme a redução que se apresenta na Figura 2:

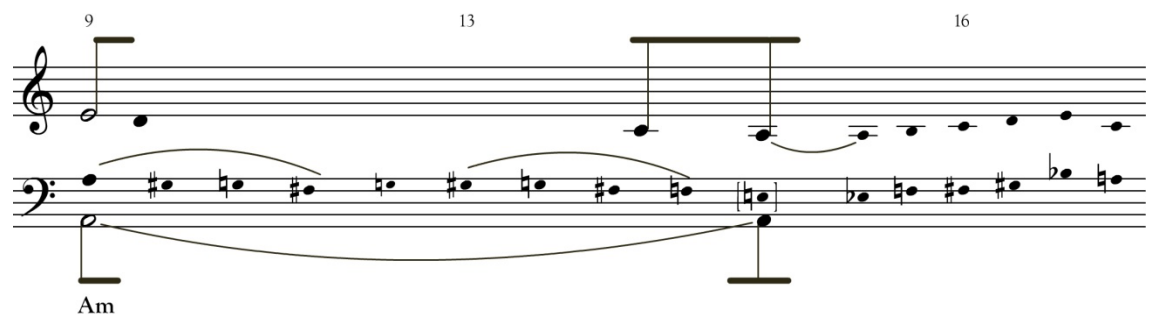

Figura 2: Redução destacando relações lineares no primeiro segmento da seção A de

"Bonita".

Nesse primeiro segmento, chama a atenção o fato de que o lugar cadencial, presumivelmente reservado para a dominante numa realização convencional da forma canção é ocupado aqui por um paralelismo melódico de trítonos que se estabelece entre as linhas do soprano e do tenor e que expande a relação de quinta diminuta apresentada na introdução da composição. Assim, a poesia - que tematiza a sedução da figura feminina idealmente projetada e que aparentemente está despreocupada com os acontecimentos no plano da estruturação formal do material musical - casa os dois últimos compassos do primeiro verso com a frase que se inicia com "Like a soft evasive [...]", em uma espécie de alusão à

26 A rememoração da polêmica à qual essa obra deu vazão poderia ajudar a compreender alguns aspectos do modo como se deu a ascensão de Jobim no campo da música popular brasileira, conferir FREITAS, op. cit., 2011, p. $75^{2-754}$. 
aparente evasão do papel estrutural reservado às harmonias da dominante. Entretanto, tanto "suave" quanto "evasivo" estão adjetivando a "névoa" ("[...] mist"), que, ao interpor-se ao objeto contemplado, confunde a percepção de sua presença. Assim, se insistirmos numa leitura harmônico funcional dos trítonos que pontuam os dois compassos finais deste primeiro segmento, podemos notar que, de modo não explícito, as harmonias da dominante da área tonal de Lá menor, o acorde de E7 ladeado por B7, a respectiva dominante da dominante, não estão totalmente ausentes nestes compassos de função cadencial.

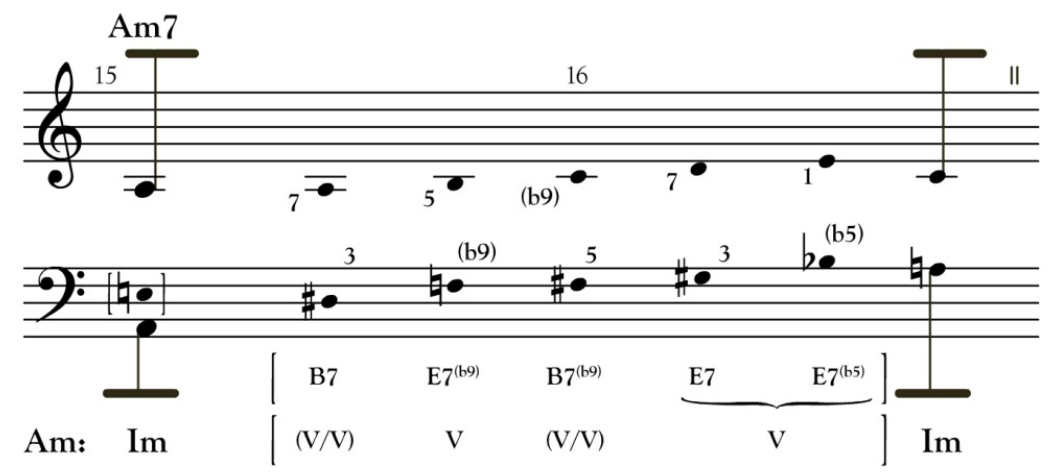

Figura 3: Uma leitura funcional do movimento por trítonos dos compassos 15 e 16 de "Bonita".

Nesse mesmo sentido, na transição para o segundo segmento de oito compassos da seção A (que acompanha as palavras "[...] mist-you are Bonita"), o contorno mi-dó no último tempo do décimo sexto compasso toma o lugar da figura melódica inicial da seção A no momento em que se inicia o novo segmento, de modo que a falta do compasso que corresponde a essa figura teve que ser compensada pela inclusão de uma pausa no quarto compasso do segundo segmento. Trata-se, novamente, de um artifício que, sem se mostrar como tal, anuvia os contornos formais da canção.

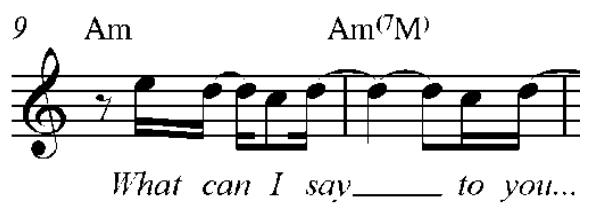

Figura 4a: Primeiros compassos do primeiro segmento da seção A. 


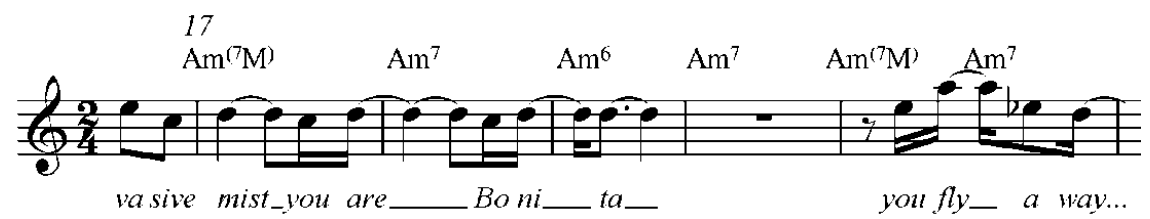

Figura 4b: Último tempo do último compasso do primeiro segmento da seção A e os cinco primeiros compassos do segundo segmento.

Esse jogo com os elementos musicais se reflete na assimetria formal criada na relação entre narrativa musical e poesia. Na comparação entre a primeira unidade de 16 compassos da seção A e a primeira estrofe da letra da canção, vemos que o início do segundo segmento de oito compassos não coincide com o início do terceiro verso ("Like a soft evasive mist - you are Bonita"), como era de se esperar, mas se situa na metade do mesmo:

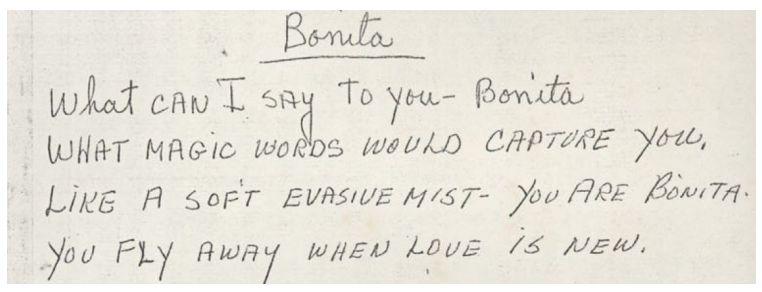

Figura 5: Primeira estrofe da versão final da letra de "Bonita". Disponível em:

http://www.jobim.org/jobim/bitstream/handle/2010/8067/bonita.pdf?sequence=20.

Acesso em: 24 fev. 2014.

É justamente o substantivo "mist" que evidencia essa assimetria, pois, sintaticamente, pertence ao complemento "Like a soft evasive", que, por sua vez, se vincula aos dois últimos compassos do primeiro segmento da seção A. Mas, em sua relação com a narrativa musical, esse substantivo coloca-se no início do segundo segmento de oito compassos, de modo que a métrica da poesia se descola da métrica musical. Com isso, levanta-se a questão de que a unidade entre letra e música, da qual resulta a canção, pode ser alcançada sem que ambas as dimensões se submetam a uma mesma lógica, e, consequentemente, sem que lhes seja negada uma autonomia própria a cada qual. A névoa altera a aparência da planta, mas não o seu desenvolvimento.

O caráter ligeiramente "nebuloso" do início da seção A se acentua na configuração dada aos terceiro e quarto segmentos (16 compassos finais). Se a finalização do segundo ocorre explicitamente com a inclusão de um acorde de tipo dominante, o D $7^{(\mathrm{b} 9)}$ no vigésimo quarto compasso, 
o acorde para o qual esta dominante secundária conduz a canção é o elemento responsável pela acentuação daquele caráter:

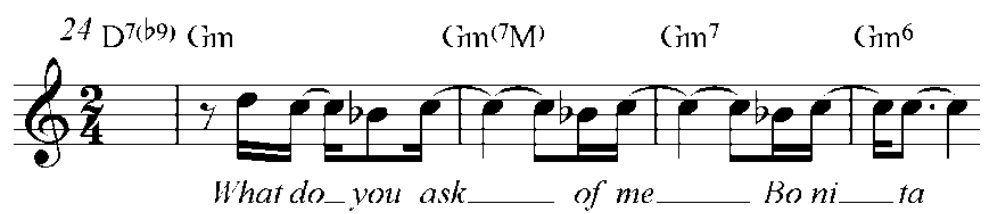

Figura 6: Último compasso do segundo verso da seção A e primeiros do terceiro.

Na introdução, o mi bemol como fundamental do acorde de Eb7 $\mathrm{M}^{(\# 11)}$ salta para o primeiro plano pela relação de trítono que estabelece com a fundamental do acorde precedente, $\mathrm{Am} 7^{(9)}$; mas, enquanto nota estranha ao diatonismo de lá menor, é tratado como ornamento ("blue note") ao longo dos dois primeiros segmentos da seção A. A situação inversa se observa no tratamento dado à outra nota que, na introdução, é estranha àquele diatonismo. $\mathrm{O}$ si bemol, que aparece discretamente na adaptação do motivo inicial da introdução para o acorde de $\mathrm{Eb} \mathrm{M}^{(\# 11)}$, ocupa uma posição estrutural nos terceiro e quarto segmentos da referida seção. É justamente essa nota que pode dissipar as névoas - adensadas pela adaptação (transposição) da mencionada linha cromática a outros acordes - que envolvem a chegada destes dois últimos segmentos. Trata-se de uma tonicização para a subdominante (Dm), cujo vínculo funcional com seu meio de preparação é dissimulado. O acorde de sol menor, enquanto IVm em movimento cadencial do tipo IVm - V7 para ré menor, é tratado com algumas das "regalias" de um acorde tonicizado, como, por exemplo, o emprego de um acorde de preparação (D7 ${ }^{(\mathrm{b} 9)}$ ), a duração temporal distendida e o mesmo "embelezamento" da linha cromática dispensado aos acordes de tônica e subdominante. Assim, dissipadas as névoas, revela-se o caráter convencional que subjaz a estrutura da seção A de "Bonita":

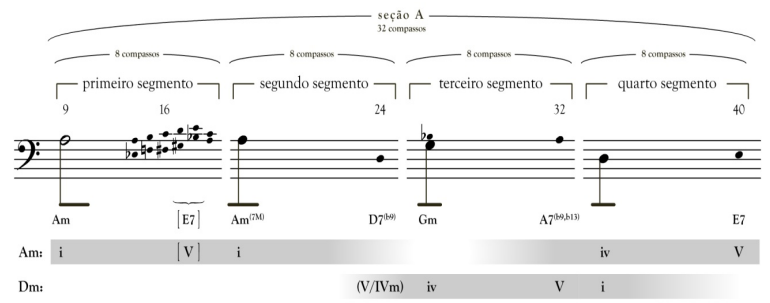

Figura 7: Uma visão do plano harmônico e formal da seção A de "Bonita". ${ }^{27}$

27 Em entrevista de 1968 a Zuza Homem de Mello, Jobim reafirma sua convicção no valor da simplicidade dos procedimentos musicais. Na ocasião, tal "simplicidade" 
Neste ponto vale a pena evocar um traço marcante do romantismo musical oitocentista que encontra parentesco em facetas da produção de música popular do século XX. Segundo Meyer, "uma das descobertas do romantismo foi como ocultar a convenção sem renunciar a ela. Os padrões estabelecidos - os gestos cadenciais, progressões harmônicas e estruturas formais do estilo clássico - podiam ser usados, mas, geralmente, eram de alguma forma disfarçados". ${ }^{28}$ A comparação se justifica também, e sobretudo, pelo seu valor heurístico para a compreensão de certas transformações vividas no campo da música popular no Brasil: a passagem de um momento em que predominava a convenção - entendida também enquanto "propriedade comum" a uma coletividade (imaginária ou real) de produtores e consumidores de música -, para um momento em que a ela se sobrepõe o qualificativo "novo" - com o qual certas práticas se diferenciam das anteriores - e, com ele, a individualidade do indivíduo criador. De certa maneira, é isso que está em jogo em composições como "Bonita". Nesta primeira seção temática, vemos que Jobim mantém em grande medida as principais funções de uma forma canção (exposição e reiteração das figuras principais nos dois primeiros segmentos, contraste no terceiro, mudança de região tonal para tonalidade vizinha etc.). No entanto, o faz jogando constantemente com os elementos formais para "enevoar" os seus contornos. É desse modo que ele inicia a seção $B$ da composição: preparando o retorno da tonalidade de lá menor, mas resolvendo na não menos esperada área tonal de Dó maior. Nesta seção B, os elementos de unidade com a seção A se estabelecem diretamente com a utilização, como meio de ligação, de um contorno melódico principal (dó-ré) análogo ao da primeira seção, e através da frase "Bonita, don't run away, Bonita":

se definia em oposição à busca pela "complicação" de elementos rítmicos, harmônicos e melódicos. Segundo o próprio Jobim, "numa sequência de música que usa $4^{\circ}$ grau, $5^{\circ}$ grau e $1^{0}$ grau (subdominante, dominante e tônica) se pode ter uma coisa da maior riqueza, não é? Ou mesmo da maior nulidade" (COELHO, Frederico O.; CAETANO, Daniel (orgs.). Tom Jobim, p. 1og). Pode-se, aqui, ouvir ecos de um tema caro à discussão de problemas estéticos que se desenvolveram na esfera da música "erudita" nas primeiras décadas do século XX: o valor de complexidade não está na coisa em si, mas nas relações entre as coisas e na densidade da ideia que as conforma.

28 MEYER, Leonard. El estilo en la música. Teoría musical, historia e ideología. Madrid: Pirámide, 2000, p. $3^{21}$. 


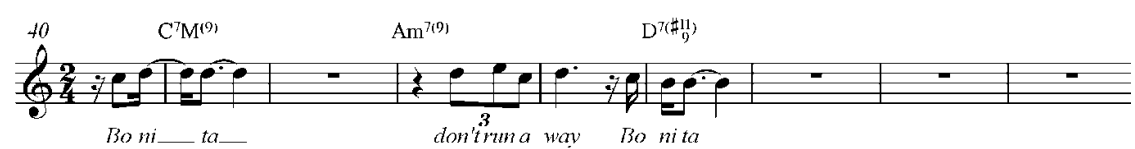

Figura 8: Último tempo do último compasso da seção A e primeiro verso da seção B

O mesmo movimento que cria unidade também cria diversidade, numa espécie de desenvolvimento dos "problemas" gerados na seção anterior. Contrastando com a seção A, temos agora um ritmo harmônico mais acentuado, uma melodia sem transposição literal de estruturas mais extensas, a supressão da linha cromática etc. E não se trata mais de desvelar as névoas que cobrem a visão da tonalidade principal (Dó maior) e suas articulações com outras regiões tonais (Lá menor, Ré menor e Mib maior), mas sim de não deixar o tom recém-instaurado fugir da compreensão ("run away"). Pois o vínculo funcional que, a partir do quarto compasso da seção B, liga o acorde de dominante da dominante (D79(\#11) à ainda mal instaurada tonalidade de Dó maior está, aparentemente, suprimido pela sua extensa duração temporal, pelos eventos harmônicos que o sucedem, e pela inflexão da escala mixolídio \#11 decorrente do emprego da nota sol sustenido na harmonia. E é novamente o si bemol, agora na forma de acorde de tipo menor com sexta, que nos dá a chave para compreender o caminho traçado pela progressão harmônica apresentada no segundo segmento de oito compassos da seção B

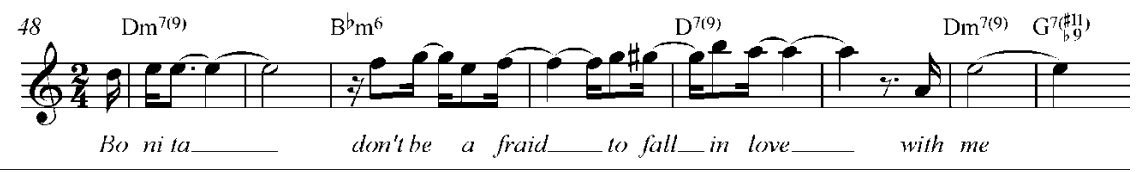

Figura 9: Segundo segmento da seção B.

Ambíguo, esse $\mathrm{Bbm}^{6}$ deixa em aberto ao menos duas compossibilidades funcionais. Em relação ao ré menor, II grau de Dó maior (a tonalidade principal), $\mathrm{Bbm}^{6}$ pode atuar como um acorde de $\mathrm{A} 7^{(\mathrm{b} 13)} \mathrm{em} 4^{\mathrm{a}}$ inversão (b9 no baixo), preparação por vezes chamada de "dominante disfarçada”. ${ }^{29}$ Em relação ao Fá maior, IV grau de Dó maior, $\mathrm{Bbm}^{6}$ atua como uma subdominante menor, e é esta função que reaparecerá reconfigurada logo adiante no acorde napolitano Gb7M (compasso 60). Nesta seção, portanto, a região da subdominante também cumpre um papel

29 Conferir CHEDIAK, Almir. Harmonia e improvisação. Rio de janeiro: Lumiar, 1986, p. 100, e GUEST, Ian. Harmonia, método prático. v. 1. Rio de Janeiro: Lumiar, 2006, p. 112-114. 
importante. Ela se afirmará ao longo do terceiro segmento, criando unidade com a seção A, e dará espaço para que a tonalidade principal da composição finalmente se afirme no último segmento de oito compassos:

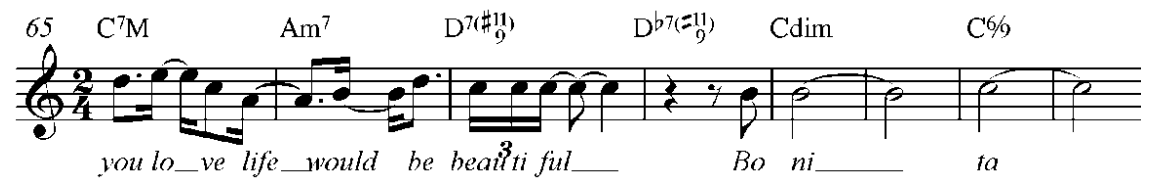

Figura 10: Último segmento da seção B

Vê-se que, na seção B, a tonalidade de dó maior se caracteriza pelo movimento de expansão para a região da subdominante (iniciado quando o centro tonal mal se havia estabelecido), e retração para a região da tônica. No movimento de expansão, a transposição da figura de segunda maior (do-ré) cria, em seus pontos estruturais, o arco melódico ré-mi-fá (compassos 41 a 53) que, no posterior movimento de retração, descende para a estabilização sobre dó: fá-mi-ré-dó-si-dó (compassos 56 a 72).

Retrospectivamente, nota-se que é justamente a resolução si-dó que está ausente ao longo de toda a composição, e que a inserção "descompromissada" do si bemol na introdução - com as suas consequências estruturais para a seção A - contribuiu para que a convencional correlação sensível-fundamental fosse evitada. Essa situação certamente não é casual, e a função estrutural que ela cumpre na composição se potencializa em grande medida na resolução com o "truque" que se esconde na passagem do acorde de dó diminuto para o acorde de dó maior (compassos 69 a 72): trata-se de uma espécie de elaboração da cadência plagal na qual a subdominante aparece como IV grau "blues", recurso que, novamente, contribui para dissimular o papel estrutural da resolução da sensível (e, ao mesmo tempo, a própria carga simbólica vinculada ao reconhecimento da figura blues $)^{30}$. Apesar de disfarçada, ou, quem sabe, justamente sob disfarce, essa passagem concentra em si todas as energias acumuladas ao longo da composição, e, em sua função sintética, ela as libera na solução do conflito lançado na introdução da canção: lá menor e mi bemol maior se "reconciliam" justamente por se vincularem à área tonal de Dó maior, a tonalidade principal, na qual, pela equiparação de relativas, lá menor aparece como região da relativa e mi bemol maior aparece como relativa maior da tonalidade homônima (Dó

zo Outra interpretação possível para esse acorde de Dó diminuto é a de que se trata de um B $7^{(\mathrm{b} g)}$ em cadência de engano para Dó maior. Essa interpretação atenua, mas não contradiz, a força da ideia que se quer enfatizar com a proposta apresentada no corpo do texto: o recurso à dissimulação atinge até mesmo o momento culminante da composição. 
menor). Nesse sentido, é interessante notar os usos da chamada "relação bifocal". ${ }^{31}$ No último compasso da seção A, a dominante de lá menor (E7) resolve sobre o acorde de dó maior, o mesmo acorde para o qual se volta a progressão cadencial $\mathrm{IIm}^{6}-\mathrm{V} 7$ para mi bemol ${ }^{32}$ nos compassos finais da seção B (cc. 63-64) $)^{33}$. Não é de nenhum modo casual, portanto, que o acorde de dó diminuto, que contém as notas lá e mi bemol, ocupe a posição de desfecho da composição, e a reiteração da resolução nos dois compassos que prolongam o último verso da seção B apenas enfatiza sua importância.

A partir desse momento de síntese é possível observar que também há uma relação "dialética" que se estabelece, no plano da melodia principal, nos desdobramentos do intervalo de segunda maior dó-ré, apresentado como gérmen da construção melódica nos primeiros compassos da seção A. Sua força generativa se manifesta não somente na conformação do arco melódico da seção $B$, mas também na construção de uma figura melódica de oposição fundamentada no intervalo de segunda menor descendente dó-si (compassos 44-45). Associado ao elemento poético central da letra da canção (Figura 11), esse antagonismo é superado justamente na conclusão da composição: o intervalo si-dó mantém a direção ascendente da figura inicial e a qualidade do intervalo que se apresenta como oposição.

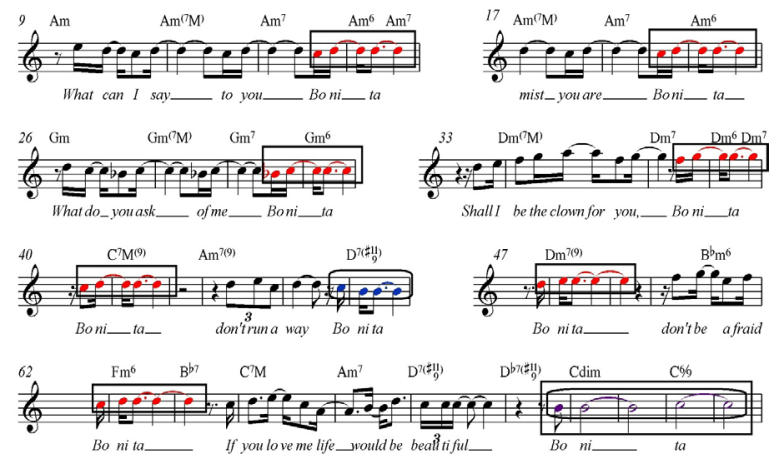

Figura 11: Explicitação do vínculo existente entre figuras melódica e poética, e da superação do conflito musical a elas relacionado.

31 LARUE, Jan. Bifocal Tonality: an Explanation for Ambiguous Baroque Cadences. The Journal of Musicology, v. 18, n. 2, p. 283-294, Spring 2001. DOI: http://dx.doi. org/10.1525/jm.2001.18.2.283

32 Essa espécie de equiparação entre relativas é conhecida na jazz theory como "The back door progression" ou "Back-door cadence". Para uma discussão que aproxima tais conceitos da ideia de "tonalidade bifocal", conferir FREITAS, Sérgio P. R. de. Que acorde eu ponho aqui?, p. 704-717.

33 Esse meio de preparação aparece nas gravações de 1964 e 1969, mas está ausente daquela lançada em 1967 , na qual figura apenas o acorde de $\mathrm{Bb} 7$, que funciona também como IV blues de Fá maior. 
O lugar em que se conforma o elemento melódico "antitético" (compassos 44-45) indica o ponto de inflexão para o qual, junto com a comentada relação entre as figuras melódicas, confluem os elementos fundamentalmente dinâmicos da construção musical. Para que essa inflexão se manifeste com nitidez é necessário, antes, comentar outra característica importante do trabalho composicional. O movimento reflexivo que estrutura a obra em torno do jogo com os elementos formais implica também a revitalização de aspectos convencionais da canção que ele incorpora, tornando-os momentos singulares e essenciais para a própria condução da forma. Nesse sentido, a aparente convencionalidade do acorde de ré maior com sétima menor nos compassos 45 a 47 - a conhecida dominante da dominante, que também tem lugar cativo no verso inicial de sessões em tonalidade maior dentro dos repertórios de distintos gêneros da música popular - é contraposta à singularidade que esse evento harmônico alcança na estruturação da forma. Além de sua longa duração temporal, intensificada pelo silêncio da melodia na voz principal, que repousara sobre a sensível de dó maior ${ }^{34}$, o caminho harmônico anunciado só será percorrido mais adiante, a partir do compasso 53. Assim, na aparente suspensão do vínculo funcional e no silêncio da voz principal, emerge uma escala octatônica de dó (cc. 47-48) - conhecida na jazz theory como si dominante diminuta, termo que explicita o uso tonal da escala. A inflexão dessa escala se configura, no arranjo de Claus Ogerman, pela união das estruturas verticais formadas com as notas dos acordes de Mib e Fá diminutos, nas cordas, e da linha melódica disposta na flauta, que percorre as notas do acorde de si diminuto:

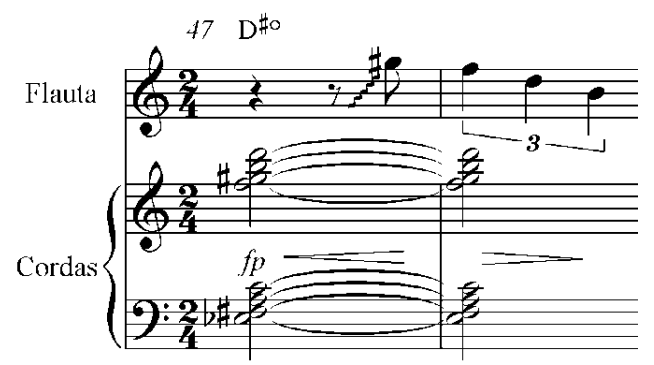

Figura 12: Fragmento extraído da partitura do arranjo de Claus Ogerman e adaptado para o compasso de $2 / 4 .{ }^{35}$

34. Vale ressaltar que dissimular elementos com forte vínculo funcional, como a sensível, é um recurso caro àqueles que se orientavam por valores como "sofisticação", "modernização" etc.

35 A cifra indicada foi extraída da linha do violão do próprio arranjo de Ogerman. Cf. OGERMAN, Claus. Bonita. Arranjo em partitura manuscrita. S/l, s/d [1967 atrib.], 
A memória desse evento ${ }^{36}$ intensifica o caráter conclusivo da composição: a tétrade de dó diminuto, acrescentada da sensível "si", num primeiro momento (cc. 69-70), e do arpejo da tétrade de ré diminuto, em seguida (cc. 73-74), resolve as tensões que se desdobraram em forma canção. Nesse sentido, o acorde de dó maior com sexta e nona (cc. 71-72 e 75-76) também ganha uma determinação particular na composição. Se, na prática da música popular, o acorde de tipo maior com sexta já era longa e amplamente tratado como possibilidade de representação da tônica ${ }^{37}$, neste caso ele contribui para a reunião e cristalização de energias da composição despedidas para a superação da "contradição" inicial: a nota lá, enquanto centro de gravidade harmônico da seção A, e a nota ré, enquanto centro de gravidade melódico dessa mesma seção ${ }^{38}$, se "libertam" da necessidade de resolução e se conservam no acorde da tônica ${ }^{39}$.

13 p. Disponível em: http://www.jobim.org/jobim/bitstream/handle/2010/4163/ bonitaClaus.pdf?sequence $=43$ Acesso em: 3 fev. 2014. Nos songbooks consultados,

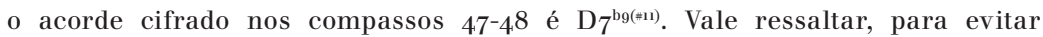
interpretações que busquem encontrar aqui alguma espécie de apologia à composição de Jobim encaminhada pela via do "ineditismo", da "originalidade" etc., que tal tipo de estrutura harmônica é recorrente, por exemplo, na música de Bartók e, na teoria, recebeu o nome de "acorde alfa". Conferir FREITAS, Sérgio P. R. de. Que acorde eu ponho aqui?, p. 775-776.

${ }_{3} 6$ A permanência de eventos fundamentalmente similares no arranjo de Eumir Deodato, registrado na gravação de 1969 com Frank Sinatra, e, sobretudo, na versão publicada no cancioneiro editado por Paulo Jobim, indica que não se trata de algo casual, mas sim de um componente importante que, assim como a introdução analisada neste trabalho, se incorporou à ideia da composição a partir da versão de 1967 .

37 Conferir SCOTT, Derek B. Sounds of the Metropolis: the 19th-century Popular Music Revolution in London, New York, Paris, and Vienna. New York: Oxford University Press, 2008, p. 47.

38 É importante ressaltar que o tratamento da dissonância enquanto nota de destaque aponta diretamente para 0 anseio "modernizante", verificável em distintas tendências internacionais no campo da música popular. Em "Bonita”, a nota ré enquanto centro de gravidade melódico da seção A coloca em evidència a dissonância de décima primeira sobre o acorde de lá menor, procedimento que encontra ressonância, por exemplo, em condutas de improvisação no jazz que se expandem a partir da década de 1950. Conferir, por exemplo, BROFSKY, Howard. Miles Davis and "My Funny Valentine": the Evolution of a Solo. Black Music Research Journal, v. 3, p. 2345, 1983. DOI: http://dx.doi.org/10.2307/779488

39 Nos arranjos de Ogerman e Riddle, a sétima maior também é acrescentada ao acorde de tônica. Mas é interessante notar que o violão, executado pelo próprio Jobim nas três gravações referidas neste artigo, parece tocar apenas o acorde de Dó maior com sexta e nona. No arranjo de Ogerman, a reiteração da passagem do acorde de dó diminuto para a tônica é colorida por uma linha melódica na flauta que, repetindo o arpejo da tétrade de si diminuto - sob a qual se esconde um acorde de $\mathrm{E} 7^{(\mathrm{b} g)}$ sem a fundamental -, interrompe o desenho descendente justamente sobre 
É também aqui que a busca por um desenvolvimento "imanente" da forma canção encontrou seus limites. Assim como a introdução, a inflexão da escala octatônica de dó nos compassos 47-48 se incorpora à ideia da composição a partir da gravação lançada no LP de 1966. É provável que ambas tenham sido introduzidas para potencializar aquele elemento que constituiria o fundamento originário da canção: as relações de trítono, que aparecem equilibradas entre o início da seção A - de maneira horizontal no paralelismo de trítonos - e o final da seção B - verticalmente no acorde de dó diminuto. Entretanto, ao incorporar a introdução e a inflexão da escala octatônica, Jobim não somente reconfigura o centro de equilíbrio da composição, mas cria um problema que permanece irresoluto. A arbitrariedade dos procedimentos empregados na introdução reivindica o poder de resolução contido nos compassos finais da seção B e em sua reiteração no coda (que também só aparece a partir da gravação lançada em A Certain Mr. Jobim), enquanto o paralelismo de trítono no sexto e sétimo compassos da seção A encontram seu ponto de equilíbrio nos compassos equivalentes da seção B pela conformação da mencionada escala octatônica. Por sua vez, ao conjugar o paralelismo de trítonos com o acorde de dó diminuto ao final da composição, essa escala cria unidade entre aquelas simetrias e potencializa o papel de síntese contido na passagem $\mathrm{Cdim}-\mathrm{C}^{69}$. Entretanto, a inevitável resolução da nota mi bemol sobre a terça maior da tônica nos faz lembrar que a polarização $A m 7^{(9)}-\mathrm{Eb} 7 \mathrm{M}^{(\# 11)}$, anunciada na introdução como "tese" e "antítese", não chegou a alcançar uma expressão condizente com o problema que ela criava. O campo harmônico de mi bemol maior enquanto "antítese", ou seja, enquanto força simetricamente oposta que disputava com a região da relativa diatônica (lá menor) o campo gravitacional da tonalidade principal (dó maior), nunca alcançou uma expressão forte; o "problema" era, de fato, um "pseudo-problema", cuja solução já estava dada de antemão pela própria forma "tradicional" da canção, que funcionava como uma espécie de subtexto para a composição de "Bonita". Parece, então, que a intensificação e a expansão da vontade de "autodeterminação" da forma faz emergir, ao mesmo tempo, a sua própria negação. Essa contradição, que se manifesta no interior das relações sonoro-musicais, é também expressão das tensões que

a sensível de lá, nota que é, em seguida, alcançada por semitom ascendente. Esse artifício, que confirma a importância estrutural da sexta acrescentada ao acorde de tônica, já fora anunciado na passagem do compasso 46 ao 47, quando a nota sol\# aparece como dissonância de $11^{\mathrm{a}}$ aumentada sobre o acorde de $\mathrm{D} 7^{(9)}$ e resolve, no clímax do desenvolvimento melódico, sobre lá, a quinta. Aparentemente casual, a importância desse evento é reforçada pelo fato do sol\# ser a única nota da melodia, na seção $\mathrm{B}$, que não pertence à escala de dó maior. 
permeavam as próprias experiências que criaram as condições para a consagração de Jobim.

\title{
Tensões e contradições: mercado e autonomia; romantismo e modernização
}

\author{
Sou contra a arte de consumo. \\ Claro, Clarice, que eu amo o \\ consumo... \\ Mas do momento em que a \\ 'estandardização' \\ de tudo tira a alegria de viver, \\ sou contra a industrialização. ${ }^{40}$
}

Para onde quer que olhemos no horizonte histórico no qual "Bonita" se constituiu como ideia, vemos passar figuras da "arte de consumo". "Kesh", pronúncia da sigla pela qual a jazz theory se refere ao tipo de linha cromática que impregna toda a seção A da composição ${ }^{41}$, evoca o aspecto comercial que envolve o emprego desse recurso. Enquanto clichê, ele ajudava a compor um estereótipo de latinidade que também revestia a circulação de produtos musicais brasileiros no mercado norte-americano ${ }^{42}$. E é a outra faceta desse estereótipo que Jobim recorreu para explicar sua atuação como violonista no disco que gravou com o famoso crooner: "eu queria acompanhar o Sinatra ao piano, mas eles me obrigaram a acompanhá-lo ao violão. 'Piano não, destrói a imagem do 'latin lover'. Tem que tocar violão". ${ }^{43} \mathrm{Na}$ poesia, toda composta em inglês, esse estereótipo encontra sua correspondência na escolha do adjetivo substantivado "bonita". Ao que tudo indica, tratava-se de atualizar a "fórmula" de "Garota de Ipanema" apelando para aquela que viria a se tornar um ícone da cultura de massas norte-americana, a atriz Candice Bergen. Nesse sentido, é relevante o fato de que as três gravações de

40 COELHO, Frederico O.; CAETANO, Daniel (orgs.). Tom Jobim, p. 143.

41 CESH, "chromatic embellishment of static harmony" ou "contrapuntal elaboration of static harmony". Conferir FREITAS, Sérgio P. R. de. Que acorde eu ponho aqui?, p. 764 .

$42 \mathrm{O}$ jornalista Burt Korall, por exemplo, comentou a música de Jobim recorrendo, por um lado, às "acentuações" e ao "colorido" do idioma e, por outro, às "qualidades rítmicas étnicas do Brasil” das quais essa música era portadora. Cf. KORALL, Burt. The Lyric Impulse. SR, o2 dez. 1967. Disponível em: http://www.jobim.org/jobim/ bitstream/handle/2010/958o/pimz16.jpg?sequence=3. Acesso em: 2 fev. 2014.

43 FREITAS, Sérgio P. R. de. Que acorde eu ponho aqui?, p. 159. 
"Bonita" lançadas entre 1964 e 1970 tenham sido realizadas nos EUA, e visavam atingir o mercado consumidor desse país. Naquele momento, em que acabara de firmar contrato com uma das principais gravadoras internacionais (Warner Brothers), Jobim estava alçando voo em busca da consagração no polo mundial de produção da cultura de massa ${ }^{44}$. Essa situação implicava uma série de concessões sobre a produção, a circulação e os direitos de suas obras. Além do prestígio de trabalhar com um músico como Nelson Riddle, havia um imperativo prático que inibia a participação de Jobim como arranjador de seus próprios discos: "Você não pode querer assumir... Entende? Uma orquestra americana que você não conhece. Você vai entrar pelo maior cano". ${ }^{45}$ No que se refere às traduções das letras de suas músicas, o problema era mais dramático e pode ser rastreado em diversas entrevistas nas quais Jobim se queixava da má qualidade das versões e atribuía essa situação ao predomínio dos interesses econômicos. Numa delas, tratou o tema como uma tragédia: "A tragédia das versões foi aquela coisa total [...]. Entra todo o problema comercial e aí você não chega nem a encontrar com as pessoas que deveriam fazer estas versões". ${ }^{46}$

É justamente nessas condições, e contra elas, que se manifesta o impulso pela autonomia do pensamento poético-musical. O cuidado que Jobim demonstrava ter com a letra de suas canções já foi especialmente sublinhado nos relatos e análises sobre as versões que delas foram feitas ${ }^{47}$. O próprio fato da poesia de "Bonita" ter sido composta

44. A própria questão ecológica, que emergia naquele período, envolvia também um lado "comercial" ligado à renovação do interesse internacional pelo Brasil pela via do exotismo.

45 COELHO, Frederico O.; CAETANO, Daniel (orgs.). Tom Jobim, p. 8o.

46 Ibidem,p. 66. O caso de "Bonita” é emblemático dessa situação. Segundo Maximiano, "O site de Tom Jobim (http://www.jobim.com.br/cgi-bin/clubedotom/musicasz. cgi. Aacesso em: 18 de jun. 2012) coloca Ray Gilbert e Gene Lees como coautores de 'Bonita', como também consta no encarte do CD Francis Albert Sinatra \& Antonio Carlos Jobim, enquanto Castro (1990) diz que a canção foi composta apenas por Tom Jobim. Lees (1998, p. 24,2) apresenta a sua versão: 'Jobim deu minha letra de 'Bonita', a qual eu havia escrito em Nova York, para Ray Gilbert, que alterou uma ou duas frases e colocou seu nome nela.' O versionista acrescenta ainda que, nos créditos da contracapa do álbum The Wonderful World of Antonio Carlos Jobim, lê-se como compositores da canção 'Jobim/ Gilbert'.” MAXIMIANO, Marina S. $O$ Brasil de Tom Jobim na voz de Frank Sinatra: um estudo sobre tradução, música e cultura. 2012. 167 f. Monografia (Bacharel em Letras) - Departamento de Letras Estrangeiras Modernas da Faculdade de Letras da Universidade Federal de Juiz Fora, 2012, p. 76 .

47 Conferir, por exemplo, MAXIMIANO, Marina S. O Brasil de Tom Jobim na voz de Frank Sinatra e GEVERS, Jeroen. Reinterpreting Bossa Nova: Instances of Translation of Bossa Nova in the United States, 1962-1974. 2010. 69 f. Thesis (Master of 
em inglês, provavelmente com a participação fundamental de Jobim, pode ser interpretado como uma luta do compositor pelo exercício do controle de sua obra. No que se refere à música, um dos objetivos deste trabalho foi justamente mostrar, a partir de um "estudo de caso", como esse impulso se desenvolveu em direção à "emancipação" de uma ideia estético-musical das contingências históricas das quais ela brotou, e sobre isso não nos resta muito mais a dizer. Cabe apenas assinalar que essa "emancipação" atinge a própria relação entre música e poesia: ao invés de um indissociável amálgama de distintas linguagens, temos uma unidade conquistada na autonomia do discurso musical. Em "Bonita", a poesia é um dos componentes principais da "névoa" que, longe de ser um entrave para a compreensão da ideia, é o meio pelo qual ela se mostra em sua autonomia ${ }^{48}$. Retornando, assim, ao "problema da forma na canção", que evocamos para construir um referencial histórico e conceitual que contribuiu para situar a análise de "Bonita", vemos que a realização da tarefa que este estudo se propôs oferece também importantes indícios de que a incorporação de valores ligados ao romantismo na esfera da música popular pode ter funcionado, paradoxalmente, como uma força modernizadora. Se o "organicismo" esteve intimamente relacionado com as teorias do "belo", e se ambos constituíram valores decisivos para a produção artística européia do período romântico (especialmente no campo da música), na esfera da produção de música popular no Brasil da segunda metade do século XX ele pode ter estimulado esse movimento de reflexividade da canção sobre si mesma e seus materiais. Enquanto fruto dos diversos desdobramentos colocados em movimento na tensão inicial claramente articulada pelo intervalo de trítono, não é mera coincidência que a solução final da passagem do acorde de dó diminuto sobre dó maior, e da sensível sobre a tônica, seja acompanhada, na poesia, pelo adjetivo substantivado "Bonita"...

Arts in Musicology) - Research Institute for History and Culture (OGC), Faculty of Humanities Utrecht University, 2010.

48 A relação entre expansão da racionalização (no sentido do domínio progressivo dos mais variados elementos musicais orientado para a previsibilidade e o cálculo) e avanço da autonomização dos valores estético-musicais, que tem como contrapartida o refluxo de escolhas orientadas pelo hábito e/ou pela tradição, foi apresentada primeiramente por Max Weber. Conferir WEBER, Max. Os Fundamentos racionais e sociológicos da música. São Paulo: Edusp, 1995, e LIMA REZENDE, Gabriel S. S. Um universo de pensamentos musicais na escrivaninha de um sociólogo: Max Weber e "Os fundamentos racionais e sociológicos da música". 2010. 275 f. Dissertação (Mestrado em Música) - Instituto de Artes, Universidade Estadual de Campinas, 2010. Disponível em: http://cutter.unicamp.br/document/?code=0oo772131. 


\section{O problema das relações entre ecologia, estética e política em Jobim}

Iniciamos nossa exposição abordando a manifestação mais visível e direta do interesse de Jobim pela natureza e destacando os matizes românticos que permeiam a forma como esse interesse se articula em um discurso ecológico. Mas, de maneira mais sutil e indireta, natureza e romantismo também se articulam em outros planos discursivos mobilizados pelo compositor. Assim, partindo daquele que se configura em entrevistas e depoimentos, abrimos uma trilha que nos levou ao nosso objetivo principal: o terreno ainda pouco explorado da influência de ideais e valores de caráter romântico no plano intrínseco de sua produção musical. O exame de "Bonita" indica que essa influência pode ser densa e relevante. Assim, se for certo que, na trajetória de Jobim, a articulação entre natureza e romantismo também alcançou uma expressão significativa no âmbito da estética, cabe perguntar: haveria um solo comum do qual ecologia e estética brotam vigorosamente? Seria este solo infértil para outros tipos de expressão? ${ }^{49}$

49 Nota-se a incidência de aspectos do romantismo que foram incorporados à fala de Jobim pela via do senso comum tanto no que se refere à questão "ecológica" quanto nas representações do artista e de seu labor. É importante salientar que o início dos anos 70 marca a ascensão, a expansão e a institucionalização de discursos ecológicos que colocavam em primeiro plano o tema da biodiversidade, de modo que o enraizamento da questão ecológica na trajetória de Jobim é consonante com tendências da época que se disseminavam pelos meios de comunicação de massa. Cf., por exemplo, NETTO, Michel N. O discurso da diversidade e a world music. São Paulo: Annablume/ Fapesp, 2014, p. 151 e ss. Por outro lado, no que se refere à influência de valores e ideais que, no plano da realização artística, remetem a problemas estéticos que orientavam boa parte da produção musical européia do século XIX na esfera da música de concerto, é possível que, em alguma medida, no campo da música popular tais valores repercutam através de um percurso relativamente autônomo em relação àquele do senso comum, ou, talvez, através de um senso comum específico do campo musical. No âmbito dos estudos musicológicos, Leonard Meyer enfrenta o problema das intersecções entre "ideologia do romantismo" e concepções musicais oitocentistas na esfera da música de concerto. Ao comentar um importante referencial discursivo e valorativo cultivado também por artistas e intelectuais oitocentistas, cujos vínculos com o tópico da natureza produziu representações das mais férteis para a teoria estética e a prática artística do período romântico, o autor destaca: "[o] organicismo foi crucial para a história da música, pois forneceu as metáforas centrais da estética romântica. Sua influência foi tão profunda e penetrante que tem durado, com ocasionais e pouco importantes perdas de intensidade, ao longo do século XX não só em manifestações da alta cultura [...]". Conferir MEYER, Leonard. El estilo en la música. Teoría musical, historia e ideología, p. 292. Citado também em FREITAS, Sérgio P. R. de. Da Música como Criatura Viva: repercussões do organicismo na teoria contemporânea. Revista Científica, Curitiba, v. 9, 2012, p. 11. Baseado nas contribuições deste autor, Freitas reitera que 0 
A questão ecológica tem um ponto de inflexão na trajetória de Jobim justamente entre finais dos anos 1960 e início da década seguinte, quando a crispação dos problemas e das posições políticas criou-lhe uma situação desconfortável nos meios musicais e na imprensa. Essa situação pode ser explicada, em parte, pelo caráter dos posicionamentos que Jobim assumia no campo político. Em certas entrevistas, há momentos nos quais, de maneira abreviada e indireta, se esboça uma postura liberal-conservadora ${ }^{50}$. Mais tarde, na rememoração daquele período, tal postura se conjugará com a oposição a tendências revolucionárias de esquerda. "Eu não sou subversivo, pelo contrário, eu sou um sujeito nitidamente da ordem e do progresso", afirmou Jobim em entrevista de 1988 à revista Veja, uma formulação que se repetiria de maneira quase idêntica na entrevista que concedera à Qualis ${ }^{51}$. Nesse sentido, no âmbito da produção de música popular em que Jobim circulava, e tendo em vista que importantes parceiros como Vinicius de Moraes e Chico Buarque de Holanda defendiam posições "de esquerda", assumir opiniões que pudessem ser vistas como "de direita" criava tensões que o compositor parecia querer evitar. O próprio bordão "direita festiva”, que Carlos Lyra cita repetidas vezes como sendo o recurso jocoso pelo qual Jobim se posicionava politicamente, pode ser interpretado como expressão do caráter hesitante dessas opiniões ${ }^{52}$. Ao mesmo tempo em que relativiza a postura recém-assumida, ser de "direita", o adjetivo que completa o bordão ("festiva") introduz um elemento de humor que tergiversa a própria seriedade que envolvia o fato de assumir aquela postura. Mas o que efetivamente se explicita - seja na paródia do bordão, seja nas entrevistas - é

organicismo é uma metáfora “crucial” [...] em meio ao alabirintado e difuso ideário musical romântico-contemporâneo" (ibidem, p. 12), e acrescenta: "[u]m organicismo contemporâneo que, disseminado no senso comum, segue a defender que as obras de arte são análogas às coisas vivas, pois apresentam os mesmos processos e se desenvolvem conforme os mesmos princípios naturais" (ibidem, p. 2). O mesmo autor, devolvendo tais valores ao conjunto de noções que se articulam no senso comum amplamente compartilhado, afirma: "O 'orgânico' é natural e se associa com concepções de gênio e inspiração, espontaneidade e liberdade, conhecimento inato e sentimento, beleza e verdade." (ibidem, p. 12).

$5^{\circ}$ Conferir, por exemplo, a citada entrevista à revista Manchete [1970] è̀ revista Qualis [1994]. Disponível em: http://www2.uol.com.br/tomjobim/textos_entrevistas_6. htm. Acesso em: 6 ago. 2014.

51 Cf. COELHO, Frederico O.; CAETANO, Daniel (orgs.). Tom Jobim, p. 170 e 193.

$5^{2}$ Conferir, por exemplo, LYRA, Carlos. Entrevista com Carlos Lyra. Contracampo, n. $4^{2}$, [s/d]. Entrevista concedida a Clara Linhart, Camila Maroja e Daniel Caetano. Disponível em: http://www.contracampo.com.br/4,2/frames.htm. Acesso em: 24 jun. 2014, e MIGUEL, Antônio C. Carlos Lyra: um bossa-nova-marxista. GI - Colunistas, 22 mar. 2014. Disponível em: http://gı.globo.com/musica/blog/antonio-carlosmiguel/post/carlos-lyra-um-bossa-nova-marxista.html. Acesso em: 24 jun. 2014. 
uma posição política que, hesitante, se refugia na ironia da "esquerda", da posição que conflitava com certos valores por ele defendidos ${ }^{53}$. Assim, num momento crítico da vida política nacional, essa hesitação também se refugiou na natureza. Em 1969, em entrevista ao Jornal do Brasil, referiu-se a sua retração à vida privada como "tempo de recolhimento". ${ }^{54}$ É nessa época também que surge “Águas de Março”, que pode ser lida como uma forma de traduzir essas angústias: a diluição - não a superação - das polarizações ${ }^{55}$. Décadas mais tarde, esse refúgio também foi registrado em sua última entrevista, concedida à revista Qualis no ano de 1994. Incomodado com a demora do entrevistador em temas que o levavam a se posicionar sobre questões políticas, Jobim interrompeu o fluxo das palavras que o conduzia por caminhos não esperados com a seguinte frase: “Tá ficando muito séria a entrevista”. Após uma pausa, a conversa adentra a natureza: "Há sessenta anos que eu vejo o mico sagui pulando aí do galho... Essa floresta é muito cosmopolita, tem jaqueira índica $[. .]. " .{ }^{56}$

Nesse período, que se estende por aproximadamente 25 anos, contados a partir da segunda metade da década de 1960, parece reafirmar-se continuamente uma profunda desilusão com o processo de modernização brasileiro, que outrora fora fundamento da "promessa de felicidade" que animara a bossa nova. Implícita na paródia que fizera da canção "Carta ao Tom" (Vinícius e Toquinho) ${ }^{57}$, essa desilusão também acompanhou Jobim até a sua última entrevista. Se em 1970, como vimos, o compositor lamentava que "Não exist[iam] mais praias na Guanabara. Existem Volkswagens. Existe poluição”, ao comentar a situação do Rio de Janeiro em 1994, ele atualiza o mesmo tom pessimista:

53 Em 1970, por exemplo, Jobim aproximou-se de Carlos Lacerda para opor-se aos "revolucionários" nos seguintes termos: "Tem outro poema aqui para nós. Não é para os pra-frentistas. Porque o pra-frentismo não sabe que o pra-frentex não é pra-frente. No dia que todo o mundo usar camisa vermelha vai ser uma monotonia total.” LACERDA, Carlos. A vida numerosa e tensa de Antônio Carlos Jobim, p. 48.

54. Cf. COELHO, Frederico O.; CAETANO, Daniel (orgs.). Tom Jobim, p. 134.

55 O próprio Jobim afirma: “Quando fiz ‘Águas de março', eu estava muito triste, estava bebendo muito, o médico disse que eu ia morrer de cirrose. 'É um resto de toco, é um pouco sozinho...' [cantando] É uma coisa que tem um lado negativo muito forte.”. Cf. COELHO, Frederico O.; CAETANO, Daniel (orgs.). Tom Jobim, p. 160.

56 Ibidem, p. 195 .

57 "Rua Nascimento Silva, 107/ Eu saio correndo do pivete/ Tentando alcançar o elevador/ Minha janela não passa de um quadrado/ A gente só vê Sergio Dourado/ Onde antes se via o Redentor/ É, meu amigo, só resta uma certeza/É preciso acabar com a natureza/ É melhor lotear o nosso amor.”. 
Você não pode andar na rua, não pode andar de carro, não pode sair à noite. Você tem que ficar pagando imposto. De um lado é o governo que quer o dinheiro, o executivo que quer dinheiro, a companhia que quer o dinheiro. E as pessoas? Para onde é que vão? O que é que elas vão fazer? ${ }^{58}$

Essa percepção de uma modernização fracassada - que não somente degrada a vida nos centros urbanos, mas que avança, com a mesma voracidade, sobre a natureza - desemboca num diagnóstico sobre as possibilidades reais de felicidade que, em certos momentos, assume feições totalizantes. Tomando alguma liberdade com as palavras de Jobim, seria como dizer: "A erosão, está tudo erodido, pra não dizer..." ${ }^{59}$ Do ponto de vista da trajetória pessoal, esse diagnóstico encontraria seu momento correspondente no ano de 1970, onde todas as vias que levariam à felicidade estariam fechadas. Após a descrição de uma vida em comunhão com a natureza feita a partir do "livro de um cara lá no sítio", que citamos nas primeiras páginas deste artigo, o interlocutor de Jobim o interrompe com as seguintes palavras: "Um momento. O que você está querendo me dizer é que se considera um homem feliz?”. Negando sumariamente tal afirmação, o compositor especula: "Certamente, perto desse hipotético sítio [...] passaria uma estrada”. E, denunciando essa via de contato com o mundo exterior, entendendo que o "progresso" estende suas raízes por todos os solos, ele deixa claro que o real está fechado para a felicidade: "Sítio bom, só nas nuvens". ${ }^{60}$

A música como meio de fuga da realidade e dos conflitos que ela engendra também foi explicitamente sublinhada pelo próprio Jobim ${ }^{61}$. Nesse sentido, na citada entrevista a Clarice Lispector, o compositor afirmou: "A criação musical em mim é compulsória. Os anseios de liberdade nela se manifestam. [...]. A liberdade total. Se como homem fui um pequeno burguês adaptado, como artista me vinguei nas amplidões do amor". ${ }^{2}$ Essa vingança, que projeta na criação musical os "anseios de liberdade" represados na vida cotidiana, realiza-se também em projeções que vinculam natureza, arte e política, como é possível depreender da resposta dada pelo compositor às críticas recorrentes na imprensa sobre a suposta visão negativa de seu país que ele propagaria no exterior: "eu deveria ser criticado pelo fato de ter descrito em minhas músicas um

58 COELhO, Frederico O.; CAETANO, Daniel (orgs.). Tom Jobim, p. 192.

59 Ibidem, p. 191.

60 Ibidem, p. 135 .

61 Ibidem, p. 73 .

62 Ibidem, p. 144 . 
Brasil paradisíaco. Como diz o Sérgio Buarque de Holanda, 'a visão do paraíso'. Quer dizer, é essa visão que eu tenho nas músicas". ${ }^{65}$

As "amplidões do amor", o paraíso, portanto, é o lugar em que a experiência dos conflitos do real projeta a reconciliação. Não se trata do Brasil histórico, em que se desenrolavam o contraditório e conflituoso processo de modernização e as lutas políticas pelo leme da história, mas sim do território que a ele correspondia no momento da conquista, e sobre o qual se projetavam as míticas imagens do paraíso terrestre. Assim, no fechamento do campo político na vida cotidiana, a relação entre ecologia, estética e política se conjuga em utopia: "Minha música é essencialmente harmônica. Sempre procurei a harmonia. Parece que eu tentei harmonizar o mundo. O que é evidentemente uma utopia. [...] mas o mundo inteiro não é utópico. O que é utópico é o Brasil. O Brasil é a grande utopia. É o paraíso". ${ }^{64}$ Não surpreende, portanto, que essa relação entre ecologia e estética tenha se mostrado mais claramente nos anos de transição entre as décadas de 1960 e 1970, período em que tanto a notória aproximação entre música popular e política quanto o desencanto em relação à modernização brasileira contribuíam para tirar o sossego de Jobim. E foi justamente Carlos Lacerda, na entrevista de 1970 da qual extraímos a citação que dá início às reflexões desenvolvidas neste trabalho, que a expôs com maior agudeza: "Seu desassossego se projeta sobre o mundo numa angústia - ecológica. [...]. Angústia de ser, de viver, que resolve seu transe, seu trauma, e se liberta - em música". ${ }^{65}$

A solução do problema assim configurado depende ainda de um aprofundamento das investigações. Somente desse modo seria possível demonstrar se ecologia e estética são, de fato, campos complementares na trajetória de Jobim, e se eles floresceram vigorosamente na infertilidade do caráter hesitante dos posicionamentos que o compositor assumia no campo político.

63 Ibidem, p. 183.

64 CEZIMbra, Márcia; CALlaDO, Tessy; SOUZA, Tárik de. Tons sobre Tom. Rio de Janeiro: Revan, 1995, p. $5^{2}$.

65 LACERDA, Carlos. A vida numerosa e tensa de Antônio Carlos Jobim, p. 49. 


\section{Sobre os autores}

\section{Gabriel S. S. Lima Rezende}

Professor de Percepção e Apreciação musical na Universidade Federal da Integração Latino-Americana (Unila). Possui graduação em Música, mestrado em Sociologia, doutorado em Música pela Unicamp e diploma de Estudios Avanzados pela Universidad de Granada/Espanha. E-mail: gabriel.rezende@unila.edu.br

\section{Rafael dos Santos}

Professor assistente doutor da Unicamp. Possui graduação em Música - Bacharel em Instrumento "Piano" pela Faculdade Mozarteum de São Paulo e doutorado (DMA) em Piano Performance And Pedagogy - University of Iowa. E-mail: rdsantos@unicamp.br 
